\title{
Pellet を産座に敷くチヨウゲンボウについて
}

加 賀崎武

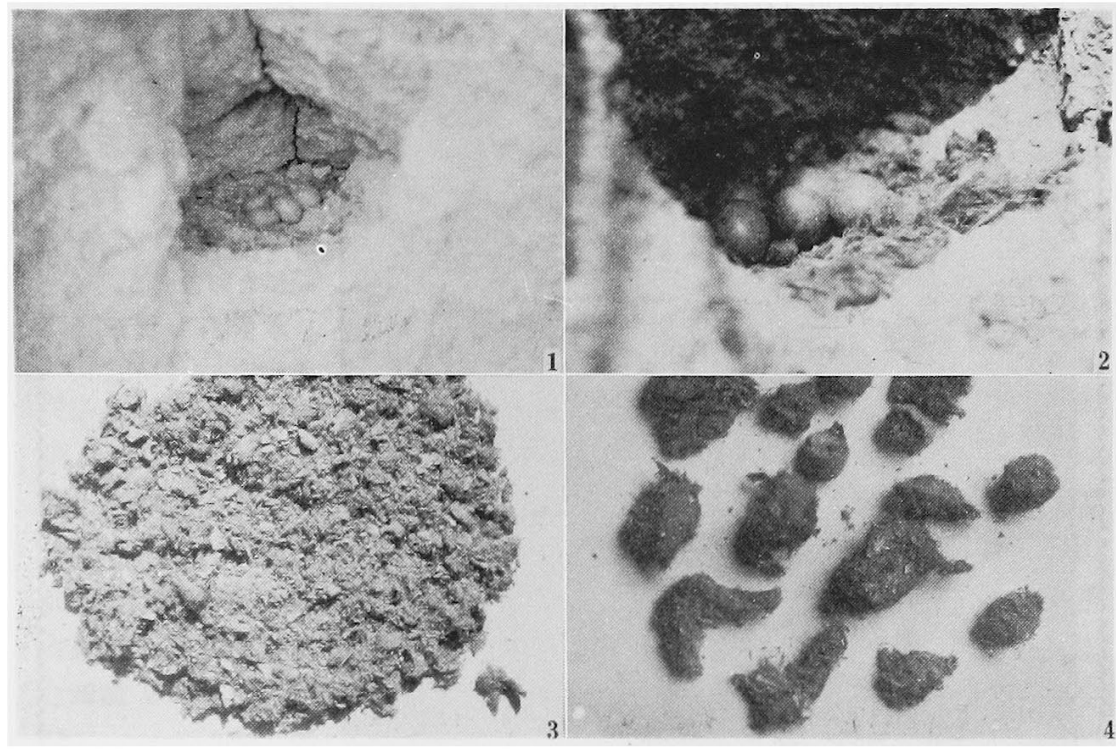

チョウゲンボウの巣内の Pellet

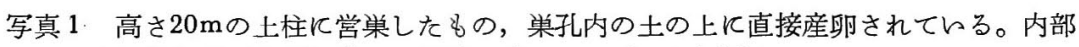
は粗砂と磁がまざり軟い。栄孔の前へロープでおり写す。

写真 2 高さ $16 \mathrm{~m}$ の崖に営巣したもので pellet が多数産座に敷かれている。産卵期間 が終った時写す。

写真 3 巣孔内に敷かれた多量の pellet をとりだしてみる。形がくすれれ砂とまじってい るが，形が認められるものも僅か残っている。ねずみ類のものが大部分である。

写真4 写真 3 の pellet から形の残っているものをとりだしてみた。とてにあるものは 総てねずみ類のものだけである。

(1960 年 4 月長野県松本市中山丘陵) 
チョウゲンボウ (Falco tinnunculus) の営栄について, 現在までに明らか になっているとこるによると，岸壁の宩孔内の土の上に巣材を全く使用せず 直接産卵するということであるが，筆者が 1957〜1961 年にかけて，松本市中 山丘陵において，21 力所の巣孔を調査した結果之のなかに6力所産座に多く の pellet 敷きその上に産卵するものがあることがわかったのでここに報告 する。

\section{調 查 地 域}

長野県松本市中山丘陵一一松本市の東南筑相山脈・鉢伏山の西麓にあたる 最も大きい独立した丘陵（慓高 $836 \mathrm{~m}$ ) であり，山頂は各所で崩壊し 8 力所 に崖をつくり，またそこには大小さまざまな土柱ができている。崖の全長は $2,000 \mathrm{~m}$ あまり，最高 $70 \mathrm{~m}$ （崖錐まで含む）に扰よぶけおしい崖がある。この 崖の各所に営巣したものについて調査した。

\section{調查方法及び結果}

中山丘陵にチョウゲンボウが蕃殖していることを確認（1957・4）したのて 1957〜1961 年に加けて，休日，早朝，夕刋をつ加，この生態の調盉につと めた。巣孔内の調査には特に困難を極め，ロープ，なわばしごを使い崖の上 端から巣孔の前面に括り，直接内部の状態を調へた。このようにして招りる ことのできないけわしい崖では，薪運搬用の鉄索で滑りおり，また鹪を組ん で内部を双眼鏡でのぞき調查した。1957～1959年までの調查において，pellet を産座に敷き産卵するものがあることがわかったので，1960，1961，と巣孔 内に敷加わる pelletについて産卵前加ら盖立ちまで，その状態，内容，その 間の覓鳥の行動について細部にわたり調查をした。

\section{巣孔の位置・大きさ・産座の状態（木の上に営巣したもの方含む）}

調查した21力所の巣について，笨孔の位置，大きさ，産座の状態を示すと 次のようである。

第 1 表 チョウゲンボウの柴穴調査表

\begin{tabular}{|c|c|c|c|c|}
\hline 年 & 番 羓孔の位置 & 栄孔の大きさ & 産座の状態 & 巣孔内調查期間 \\
\hline 1957 & 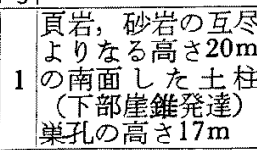 & $\begin{array}{l}\text { 長窐 } 30 \mathrm{~cm} \text { 短佳 } 20 \mathrm{~cm} \\
\text { (楕円形) 奥行 } 35 \mathrm{~cm} \\
\text { 稍奥一傾刹 }\end{array}$ & 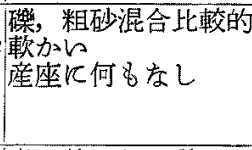 & 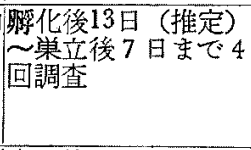 \\
\hline 958 & \begin{tabular}{|l|l} 
& 1 と同じ場所
\end{tabular} & 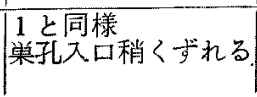 & $\begin{array}{l}\text { 産訵前より pellet } \\
\text { 整々 } 1 \text { と同様 }\end{array}$ & $\begin{array}{l}\text { 産則前12日〜单立後 } \\
5 \text { 日 (推定) まで4 } \\
\text { 回調查 }\end{array}$ \\
\hline
\end{tabular}




\begin{tabular}{|c|c|c|c|c|c|}
\hline 年 & 番 & 宩孔の位置 & 栄孔の大をさ & 産座の状態 & 畄孔内調査期間 \\
\hline \multirow[t]{3}{*}{1958} & 3 & $\begin{array}{l}\text { 南面した高さ16m } \\
\text { 崖 } \\
\text { 亲孔での高さ15 } \\
\mathrm{m} \\
\text { 下部崖錐発垟 }\end{array}$ & 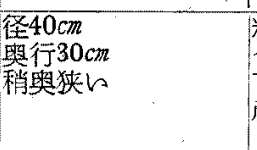 & $\begin{array}{l}\text { 粗砂に少し角礫が混 } \\
\text { 合部固に } \\
\text { 産座に何もなし }\end{array}$ & $\begin{array}{l}\text { 産卯後10日 (推定) } \\
\text { 策妾後 } 3 \text { 日調査 }\end{array}$ \\
\hline & 4 & 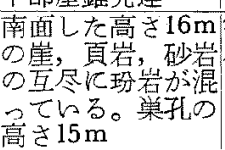 & $\begin{array}{l}\text { 堡 } 30 \mathrm{~cm} \\
\text { 臭行 } 30 \mathrm{~cm}\end{array}$ & 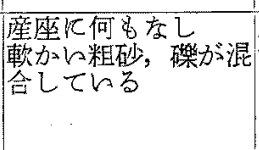 & 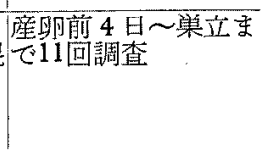 \\
\hline & 5 & 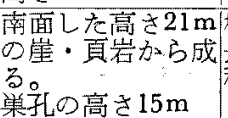 & 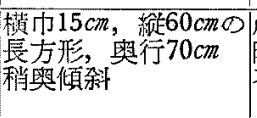 & 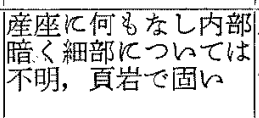 & $\begin{array}{l}\text { 㦃卵後7 日 (推定) } \\
1 \text { 回調査, 内部電燈 } \\
\text { 飞調查 }\end{array}$ \\
\hline \multirow[t]{5}{*}{1959} & 6 & 1 と同じ場所 & 1 と同様 & 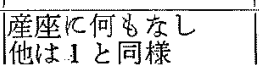 & 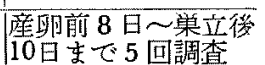 \\
\hline & & 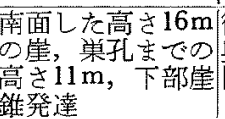 & $\begin{array}{l}\text { 窒30cm } \\
\text { 與行 } 35 \mathrm{~cm} \\
\text { 形 }\end{array}$ & 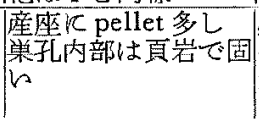 & 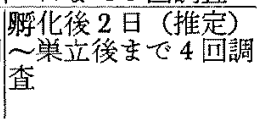 \\
\hline & 8 & 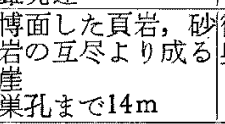 & 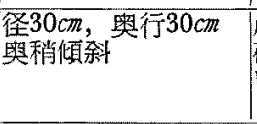 & 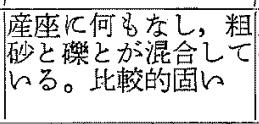 & 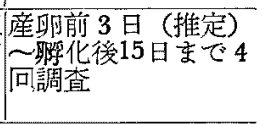 \\
\hline & 9 & 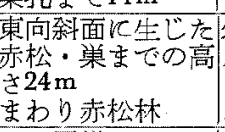 & 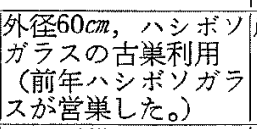 & 産座に & 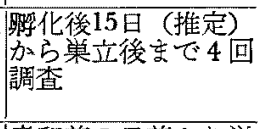 \\
\hline & 9 & 3 と同粎 & 3 と同椂 & $\mid \begin{array}{l}\text { Pellet 産卵前がら } \\
\text { 多く敷く。 }\end{array}$ & $\begin{array}{l}\text { 産卵前 } 5 \text { 日前より笨 } \\
\text { 租後10日まで12回調 }\end{array}$ \\
\hline \multirow[t]{6}{*}{1960} & 11 & 1 と同じ場所 & 1 と同様 & 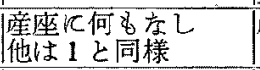 & $\begin{array}{l}\text { 産卵前10日〜㮐立後 } \\
5 \text { 日さで8回調查 }\end{array}$ \\
\hline & 12 & 7 乙同じ場䏳 & 7 已同様 & 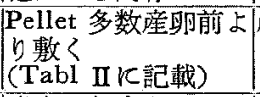 & $\begin{array}{l}\text { 産卵前 9日棠立後 } \\
\text { まで18回調查 }\end{array}$ \\
\hline & 13 & 8 と同じ場所 & 8 と同様 & 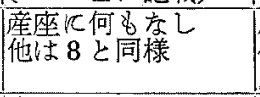 & 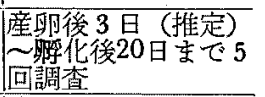 \\
\hline & 14 & $\begin{array}{l}\text { 南刹面赤松栄亡で } \\
9 \mathrm{~m}\end{array}$ & 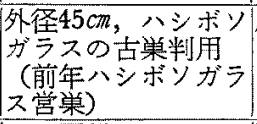 & 産座に新しにものな & $\begin{array}{l}\text { 産卯後 4日 (推定) } \\
1 \text { 回調查 }\end{array}$ \\
\hline & 15 & 3 と同じ場所 & 3 と同様 & 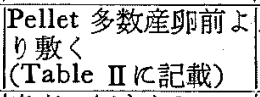 & $\begin{array}{l}\text { 産卵前14日より巣立 } \\
\text { 後をで18回調查 }\end{array}$ \\
\hline & 16 & 5 と同じ場所 & 5 と同様 & 産座に何もなし & 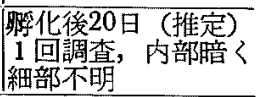 \\
\hline 1961 & 17 & 1 と同じ場所 & 1 と同様 & $\begin{array}{l}\text { Pellet 少乙敷く } \\
\text { 他は } 1 \text { と同様 }\end{array}$ & $\begin{array}{l}\text { 産卯前 } 7 \text { 日 卿化後 } \\
20 \text { 日まで } 6 \text { 回調查 }\end{array}$ \\
\hline
\end{tabular}




\begin{tabular}{|c|c|c|c|c|c|}
\hline 年 & 番| & 豐孔の位置 & 宩孔の大をさ & 産座の状態 & 单孔内調查期間 \\
\hline \multirow[t]{4}{*}{1961} & 18 & 7 と同じ場所 & 7 と同様 & $\begin{array}{l}\text { |産坐に何もなし } \\
\text { 岩で固々 }\end{array}$ & 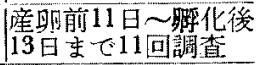 \\
\hline & 19 & 8 と同じ場所 & 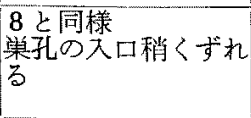 & 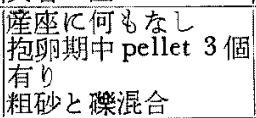 & 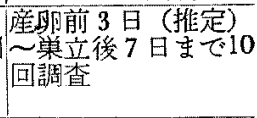 \\
\hline & 20 & 3乙同し場所 & 3 乞同様 & $\begin{array}{l}\text { 産座飞何字し } \\
\text { 粗砂多く比較的軟々 }\end{array}$ & 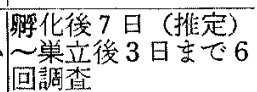 \\
\hline & 21 & 5 と同じ場所 & 5 と同様 & $\begin{array}{l}\text { 産座に何むなし } \\
\text { 嘪で固い }\end{array}$ & 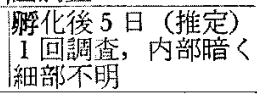 \\
\hline
\end{tabular}

第 1 㤗に和いて果孔番号

$$
\begin{aligned}
& 1,2,6,11,17 \text { は同一䉓孔 } \\
& 7,12,18 \text { は同一㴪孔 } \\
& 3,10,15,20 \text { は同一柴孔 } \\
& 8,13,19 \text { は同一笨孔 } \\
& 5,16,21 \text { は同一巣孔 }
\end{aligned}
$$

○は産座に Pellet が敷がれて々た巣 $(2,7,10,12,15,17)$

以上調育した 12 加の巣孔について記した。この結果抱卵中に2，3の

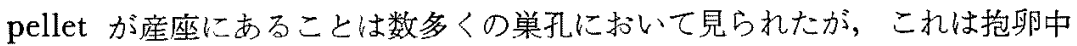

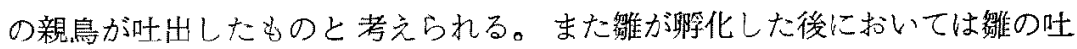
出した pellet（あまだれ形の小さいるの）や，食物として運ばれてきた小鳥 類の羽毛，食べ残しの頭部，足などが宩孔内に散乱している場合が多かった。 しかし第 1 表の $1,7,10,12,15,17$ に示した单孔の場合は産卵数日前から多量 の pellet 加産座に厚く敷かれその上に産卵されることから， pellet が巢材 として使われていると考方られる。この場合 pelletを敷くものと教かないる のが栄孔の条件，環境とは何等の関係も見いだせない。また個体によって pellet を數く能力古持つものと持たないるのがあるといらことも考えられる が,この点については不明である。

\section{栄孔内の産座に pellet が敷かれていく状態}

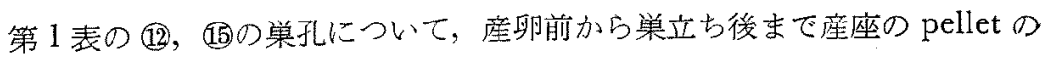
状態を調へたたりのを示すとつぎようである。 
第 2 表 覓 12 抢よび 15 (第一表) の観察

\begin{tabular}{|c|c|c|c|c|}
\hline & & 12 の单 & & 15 の 相 \\
\hline 月日 & 調査期間 & Pellet の状態, 親鳥の行動 & 調查期間 & Pellet の状態, 漞鳥の行動 \\
\hline IV & & & & \\
\hline 3 & AM 6-7 & 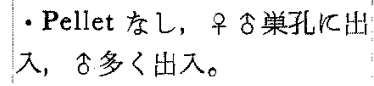 & & \\
\hline 4 & & & & 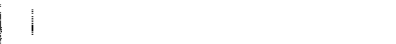 \\
\hline 5 & 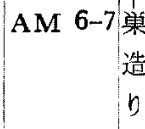 & 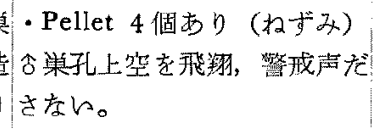 & AM 5-6 & 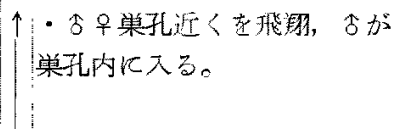 \\
\hline 6 & 期 & & & \\
\hline 7 & 間 & & & \\
\hline 8 & AM 7-8 & $\begin{array}{l}\text { Pellet の数多くなる。形の } \\
\text { はっきりしたbの15こ，各市 } \\
\text { 栄孔k出入している。 }\end{array}$ & AM 6-7 & 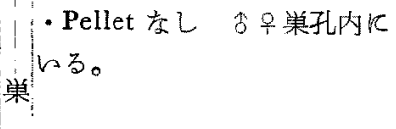 \\
\hline 9 & $\downarrow$ & & & \\
\hline 10 & 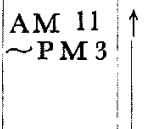 & $\begin{array}{l}\text { - Pellet の数ふよそ30個单孔 } \\
\text { 内全体に広がる。一卵あり市 } \\
\text { 警成声をだし飛びまわる。 }\end{array}$ & AM9-11 & - Pellet 3 個（放ずみ）。 \\
\hline 11 & & & & $b$ \\
\hline 12 & & & & \\
\hline 13 & AM 6-7 産 & $\begin{array}{l}\text { Pellet の数10日の調査と変 } \\
\text { らず, 三卵になる。文抱卵。 }\end{array}$ & AM 5-6 & $\begin{array}{l}\text { ・Pellet 12個形がはっをりし } \\
\text { ている。(ねずみのものが多 } \\
\text { く僅か小鳥類のタのもあり)。 }\end{array}$ \\
\hline 14 & 期] & & & 間: \\
\hline 15 & 間 & & & \\
\hline 16 & P M 3-5 & 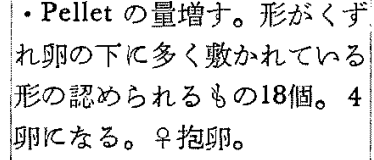 & P M 5-6 & $\begin{array}{l}\text { ・Pellet およそ20個，中央部 } \\
\text { のものは形がくずれている。 }\end{array}$ \\
\hline 17 & $\downarrow$ & & & \\
\hline 18 & AM 6-7 & $\begin{array}{l}\text { ・Pellet は綿状になり，形の } \\
\text { 認められるもの16個，5卵に } \\
\text { なる親鳥の姿は見られない。 } \\
\text { ・新らPellet 2 個むん他は }\end{array}$ & AM 7-8 & 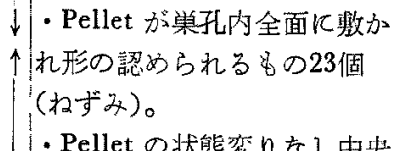 \\
\hline 19 & AMM $\quad 0-7$ : & ・新しhPellet 2 個あり他は & $A M \quad 7-8$ & $\begin{array}{l}\text { ・Pellet の状態変りなし中夹 } \\
\text { K1 畉あり 早栄内にいる。 }\end{array}$ \\
\hline
\end{tabular}




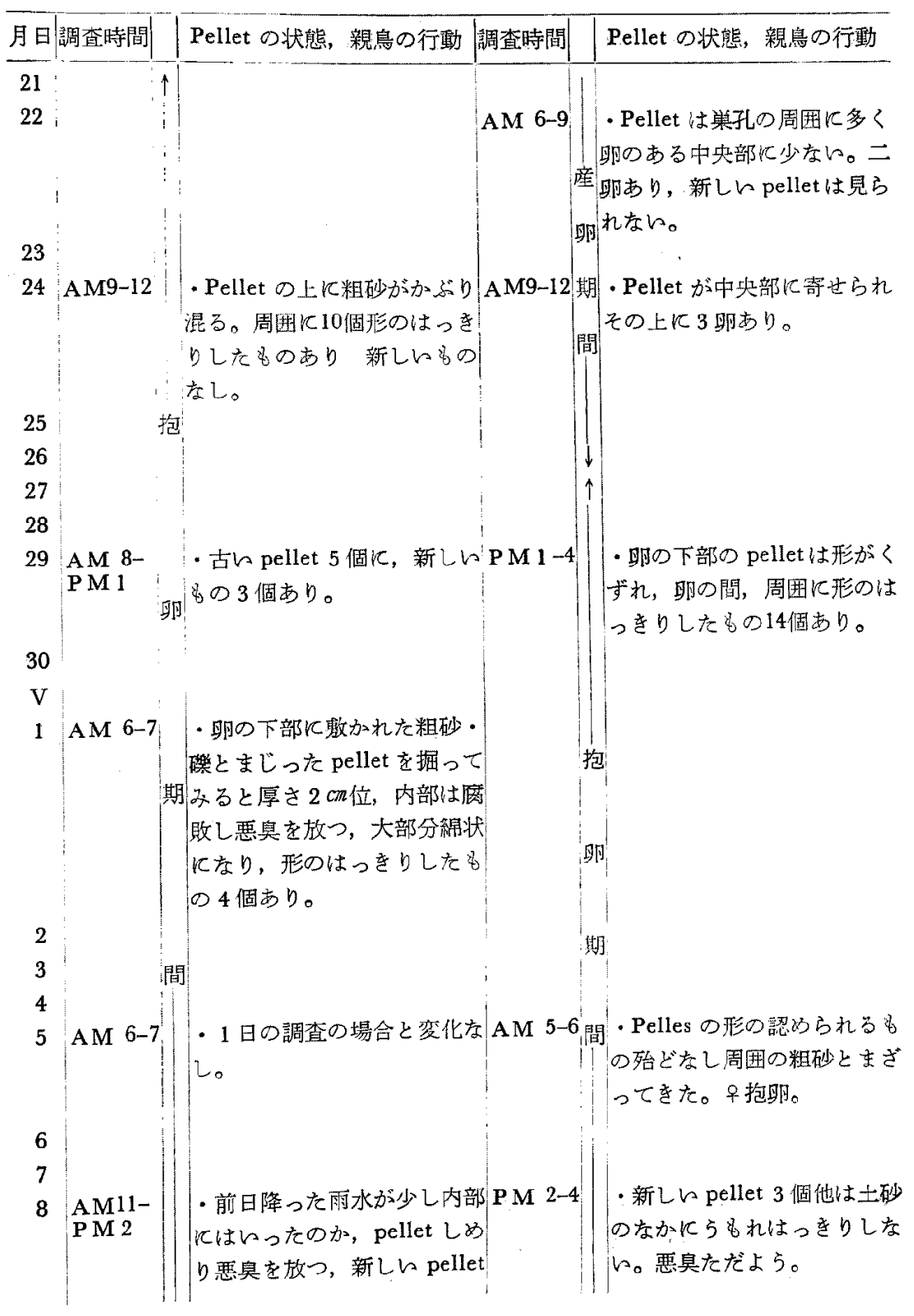




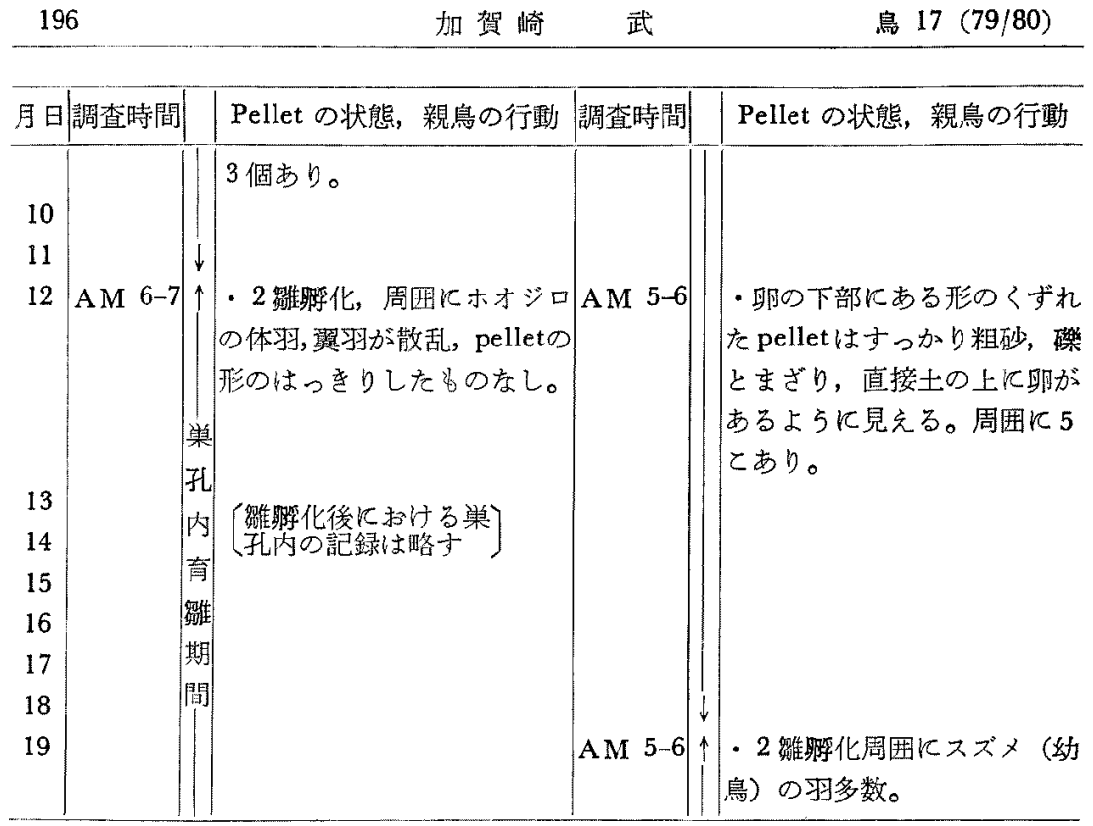

第 2 表に示すように，巣孔の潠択が終ると産卵までに多くの pellet を産座 に敷く。(12)の巣孔に执いては産卵前 5 日から，(15)の巣孔に扣いては 9 日前か ら数個の pellet が巣孔内にあり，その数は産卵が近つくに往い数を增し，産 卵直前には巣孔内全体に敷かれていた。敷かれた pelletの多くは，㸚すみ類 のもので，その中に僅か小鳥類のものがまじっていた。この pellet は総て新 しい（湿っている。巣孔内の粗砂がまわりについている等のことから）むの で，親鳥が巣孔内で直接吐出したるのであり，他加ら運びこんだものとは考 えられない。

産卵が始まる頃加ら pellet の形はくずれ，毛や羽は黒い綿状になりその中 に骨が散吉しているのが見られた。やがてそれらは粗砂，碟とまざり，pellet として区別のつくものは周囲に僅加残るだけとなる。抱沺中に時ょ新しい pellet が見られたが，これは抱眆中の親鳥が吋出したものと考之られる。抱

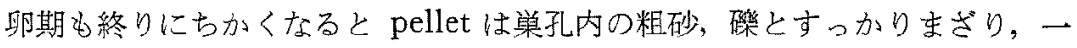
見土の上に斾があるかのように見える場合むある。雨の日などは pellet がや や湿り笨孔内をのぞくと悪臭がたたよう。䍙が泖孚化すると，これらの pellet と, 食物として運ばれてきた小鳥類の羽毛, 食へ残しの頭部, 微の吐出した pellet が巣孔内に散乱するようになる。雛が成長して巣孔内での動きが活溌 
になるとこれらは策孔内にふみこまれ，あるものは巣孔外に落とされ何必な いような状態に变ってしまう。

結 ひ

トラフズクヤナギフタロウなどは，自分の德場所へ pellet 在吐出し，た めて扮くということが知られているが，キョウゲンボウの場合は，座卵前巣 孔内及び外部崖下などに罴が見られないことからこの巣孔を德湯所にした のではないと考えられる。また自分のなわばり内に pellet を吐出するモりフ クロウの例などす知られている加，このことから紧れを自分の所有下に妨く 行動として， pellet 栄孔内に时出して扰くとうことも考えられるが，座 畉前に多数産座に敷かれることから，この pellet は篓材として使用されてい るのではないかと思われる。

\section{参考 文 献}

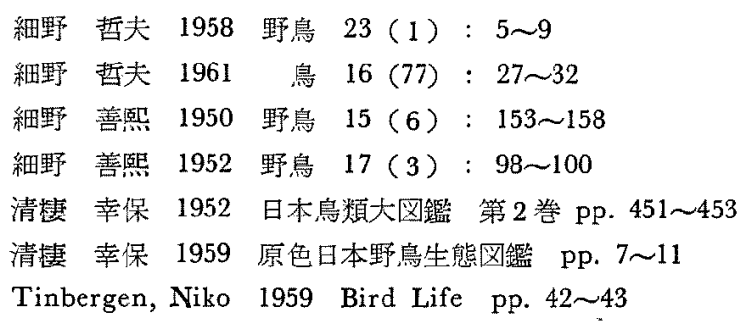

Kagasaki, Takeshi : A note on pellets in the nests of Falco tinnunculus in Nagano Pref.

Pellets are deposited in the nest before egg-laying and are increased later. Pellets of chicks also became mixed and are tramped by them. Pellets are thus considered to serve as nest-material. 